\title{
Preliminary Research Description In Developing Tematics Learning Materials by Using Character Building and Discovery Learning to Establish Children aged 6-9 Years
}

\author{
Hendrizal \\ Primary School Teacher Education Department \\ College of Teacher Training and Education of Adzkia \\ Padang, Indonesia \\ hendrizal75@yahoo.com
}

\author{
Chandra \\ Primary School Teacher Education Department \\ Universitas Negeri Padang \\ Padang, Indonesia \\ chandra@fip.unp.ac.id
}

\begin{abstract}
The realization of character building in the learning process becomes the purpose of analysis in this research. The analysis of this study was conducted to overcome many attitude problems in the elementary school through the process of education in the schools. The research process was done by using Ploomp model which grouped into 3 steps, namely Preliminary Research, Prototype Pase, and Assessment Stage. The research finding in preliminary were children aged 6-9 years who need integrated thematic materials based on character education have characteristic: $50,79 \%$ of them have hobby of playing with various types of games, $38,10 \%$ of them like red color, $53,97 \%$ of them like food with material chicken, $37,30 \%$ of them like cartoon character figure, $42,06 \%$ of them like apple with, $48,41 \%$ of them, likes spinach and $68,25 \%$ of them like type of drink with juice percentage. This analysis shows an early description of the character of children aged 6-9 years which is very useful in making teaching materials for the realization of character building.
\end{abstract}

Keywords—preliminary research; tematics learning materials; character Building

\section{INTRODUCTION}

The problem of character building in elementary school becomes the main highlight which concerned in education in Indonesia. It occurs because there are many negative attitudes that were done by the students nowadays[1]. It happens not only in teaching learning process but also when they have interaction with other students. One of the problems that become concerned in education world especially in elementary school, for example, LBH (Legal Aid) Padang city, November 23, 2014, some case was done by elementary school' students, such as: gambling, skipping, immoral, and violence (www.aktual.com, December 23, 2014). This fact showed that the student of elementary school did not obey the rules of their school[2].

Based on current children's issues, it is necessary to apply character building in school(Jorgensen \& Stedman, 2001). The character building in elementary school is important and urgent. Elementary school is an appropriate place to build the character or to create good moral value for the students supporting by the good atmosphere[4].

In fact, it found that it has createdthe students with a bad attitude so this country will also produce the human being with bad attitude[5]. The assumption is learning the process in elementary school for implamenting the values to the students, because elementary school' education is a first step to build the next young generation character[6]. The character building is the main concerned in education, so the goverment has intergrated the character building in education, begin from competency-based curriculum (2004), then, level education unit curriculum[7]. The last, the character become one of competency that determine the achievement of education through 2013 curriculum[8].

In 2013 curriculum, Students' competence is developed as main competence. It is designed in line with the increasing age of students in a particular class. Vertical integrated on various basic competences in the different class can be maintenance through main competence. The formulation of main competence uses this following notation: (a) main competence 1 for spiritual behavior, (b) main competence 2 for social behavior, (c) main competence 3 for knowledge, (d) main competence 4 for ability. Behaviors competence (spiritual and social) requires students to have thinking ability and act productively and creatively in the abstract and real field based on what has assigned to them. Therefore, a teacher should have a creative way to create an effective learning process in order to optimize the competence that has been explained[9].

Based on the result of document analysis from a material that was used in a school, it found that some material that was used by the teachers still have some weakness. It can be seen through main competence and problem formulation. Character building is still in introduction level[10]. Character building presented in the teaching materials has not suggested students to apply the character[11]. The material was used by the 
teacher just explain students about one character[12]. Basically, 'students' book' should help students to understand the character and morality and introduces the value of cognitive way. It means that the value or character is reasonable for them. Furthermore, it can also help students to comprehend the value with the affective way[13]. So the students can think what the significant character is and what is the impact can appear if it is not done and at the end, students can see the valuable experience in a real way. Thus, it facilitates the students to practice that character in their real life. Based on preliminary research that the authors did in schools implementing the 2013 curriculum obtained information that are problems in the implementation, These problems were: (1) some students acted disrespectfully to other students, (2) teaching learning process was still to answer the question in students' book, (3)teacher was dominant in teaching learning process (4) it was still question and answer system between teacher and some students, so teaching learning process became monotonous, (5) the learning was not developed students activity in giving opinion, gave questions, even caused a negative activities such as played, walked around the class (6)less interaction between teacher and students or students and students in learning process. Based on the problems that have been explained above, it is necessary to provide the teaching materials to support thematics learning process that is integrated the character building. Kemendikbud (ministries of education and culture) (2013) gave a directive that the development of thematic material was the main terms in order to achieve successful in teaching and learning process.

The explanation above implies teachers to develop teaching materials that can create an effective teachinglearning process based on the students' character, the current development, and surrounding environment needed. One of the teaching materials that can adopt this characteristic is the materials of thematically integrated that can integrate the character building based on discovery learning [8][14][15], [16][18].

Good or bad person character can be seen from their everyday habit. Someone has a good character if in their real life has three habits: habits of mind, habits of the heart, habits of action[19]. Based on the explanation above it can be said that character is a self-illustration such as an attitude, action, and behavior that can be seen from their habit. The right character for education consists of an operative value, action value includes three parts, morality knowledge, morality feeling, and morality behavior[19]. Moreover, education character is a process of giving guidance to students become a real human being, having a character in heart dimension, mind, body, feeling, and intention[20]. In addition, character building is an effort to understand, create, implement and teach the value of ethics, for theirself, society or even for the citizen. The character that develops in this research includes five values: (1) honest, (2) discipline, (3) responsibility, (4) well mannered, (5) care, and (6) confidence[21]. Learning of implementing behavior can be taught in thematics learning. Furthermore, thematics learning is a learning that includes some subjects to give some experience to the students[22].

\section{RESEARCH METHODS}

Development model was used adapted from McKenny model. It consists of three main steps: (1) preliminary research, (2)prototyping phase, and (3)assessment stage [23]. Preliminary research: need analysis, content analysis, literature purpose, the development of the conceptual framework. Prototype stage: design of the prototype, the evaluation to increase the product that is designed. Assessment stage: evaluation to get information whether the product has to fulfill specification rule or it needs revision.

Preliminary research: the purpose of this step is to decide and define the requisites that are needed to develop the material. This activity analysis consists to six aspects, they are curriculum aspect, concept, students, material (teacher' book, student' book, and lesson plan), discovery learning, the literature of character building.

Prototype stage: the activitiesin this stage are to make a prototype plan, evaluation, and revision with the purpose to create materials, and thematics lesson plan based on discovery learning for fourth-grade students that have high quality.

Assessment stage: in this stage, the effectiveness of product will be tested. The effectiveness of product means a measurement to find the effect of the product to the users. Effectiveness aspect is observed in the learning process by using thematics material integrated with character building.

\section{RESULT AND DISCUSSION}

The result of Preliminary Research Description in Developing Thematic Learning Materials by Using Character Building and Discovery Learning in the step of the preliminary research can be served as follow: analysis is done toward 2013 curriculum, students' book, materials needed, and students' characteristics.

Need analysis thas is done toward the material refers to two main aspects: content and design. Curriculum analysis that is done to analyze the main competence and basic competence, concept, and assignment. Analysis of students' characteristic is done to know the material suitability that has developed with a level of students' development. The result as follow:

\section{A. Curriculum Analysis}

Based on the result of material document analysis that was used in the school, it found that lesson plan that is used by teacher still has a weakness. The problems can be seen from basic competence and formulation of the problem. For example, basic competence and formulation of the problem are not suitable for knowledge and skill inthe material (teachers' book).

The mapping of basic competence is not appropriate for fourth-grade students. Based on contents ofPJOK (Physical Education, Sport, and Health) learning, there is 2 basic competence that will be achieved, basic competence number 3.2 for knowledge and basic competence number 4.1 for skill. The basic competence has just one indicator and it is not clear whether knowledge indicator and the skill have formulated. It also happened in IPS (social sciences) subject, it was only one indicator and it was not clear too. Then, PPKN(Pancasila and citizenship education)subject had 3 basic competence that will be achieved, such as Bc 3.1 and 3.4 for knowledge and Bc 4.1 
for skill. It means, it still needs to add one Bc about knowledge, it is Bc 4.4.So,it will be in line between knowledge and skill to be achieved.

Next, character buildings in the students' book are just only an introduction about what students must do. This is a part of education character in student's book. It can be seen in picture1.

Picture 1.Illustration of character building in students' book (Kemendikbud, 2013:92)

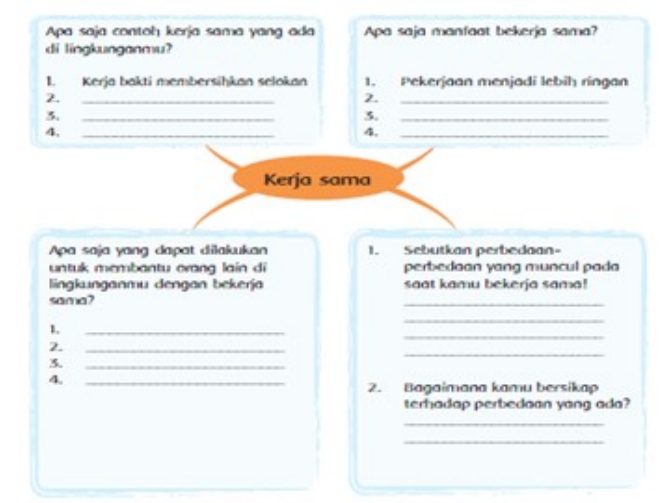

Based on picture 1 above describes that character building just for introduction. In this case, students only are giventhe knowledge of character, but the students' book should facilitate students to understand the character or morality value with cognitive way. It means value of the moralityis logically for them. Then, this book also can make them understand and make them can think the use of a good character or they can understand what are the effect will be assured if they do not have good character or morality value in their real life. The last, this book also can facilitate them to practice this value in their daily activities.

\section{B. Concept Analysis}

According to Rusman (2012:260) the scope of thematic learning development encompasses the entire content of subject in class I, II, and III of elementary school, namely the content of learning religion, Indonesian Language, Mathematics, Natural Science (IPA), Pancasila and Citizenship education (PPKn), Social Sciences (IPS), Cultural Arts and Workshops (SBDP), as well as Physical Education, Sports, and Health (PJOK).

Indonesian Language lesson consists of four skills, namely listening, speaking, reading, and writing skill. According to Yunus (2012: 94), "Listening is a deliberate intention to grasp the sound of a language even though it has not been oriented to the formation of an understanding of the message contained in the sound of the language". Kundharu and Slamet (2012:34) state that, "Speaking is a means to communicate ideas which are organized and developed based on the needs of the listener. Cox (in Jonah, 2012:148) states that reading is a psychological process to determine the meaning of written words. Tarigan (2008:27) suggests that "Writing is to show or to draw graphics symbols to describe a language that a person understands so that people can read the graphic symbols if they understand the language and graphic representations".

Science subjects are the subjects related to living creatures and the surrounding natural environment obtained by systematically finding out about nature. The scope of IPA (Natural Sciences)according to MoNE (2006:485) are (1) human beings and their life processes, (2) things, (3) energy and its change, and (4) earth and universe.

IPS (social sciences) study about a set of events, facts, concepts, and generalizations related to social issues. In elementary school level, IPS subjects include materials geography, history, sociology, and economics. Through IPS subjects, students are directed becoming democratic and responsible Indonesian citizensand also becomea peace-loving world citizen. The learning objectives of Social Studies by Banks (in Sapriyadi, et al, 2006: 18 are: "(1) knowledge, (2) skills, (3) attitudes and values, and the actions of citizens."

While Somantri (in Aziz, 1999:14) states that PPKn (Pancasila and citizenship education) is a social subject that aims to foster and develop students to become good citizens. Good citizens are citizens who know and are able to do good things or in general who know, realize, and do their rights and duties as a citizen.

According to the Ministry of National Education (2006: 416), "Mathematics is a universal science that underlies the development of modern technology, has an important role in various disciplines to develop the human mind." The scope of the subjects of Maths (2006:417) is (1)number, (2) geometry and measurement, and (3) data processing.

The field of study of Cultural Arts and Workshops according to MoNE (2006:610), is a field of study that has multilingual, multidimensional and multicultural. It has a role in the personal student harmonious formationbased on students' development need in achieving multiple intelligences.

\section{Characteristic Analysis of Learners}

Characteristics of learners aged 6-9 years can be reviewed from several types of development, namely: physical-motor development, intellectual development, language development, emotional development, and social development. This analysis is required before designing the teaching materials. According to Uno (2007:27) 'identifying the behavior and characteristics of learners is necessary to do in order to know the quality of individuals who can be used as a guide in learning planning. Analysis of the characteristics of learners made as a basic reference to developingthe integrated thematic materialsof character building and discovery learning in elementary schools.

Analyzing the level of language development of learners is used for consideration in preparing the language of teaching materials. Analyzing the intellectual development of learners is used for consideration in setting the level of difficulty of problems in the text reading material and answering questions. While analyzing the physical-motor development, emotional development, social development, learning motivation learners are used for consideration in designing the presentation of teaching materials to make learners interest or make give them motivation in learning.

The results ofcharacteristics analysis of learners aged 6-9 years in SD Negeri 41 Sawahan districts of East Padang and Adzkia Elementary school of Kuranji districts, Padang City.The elementary school students with 6-9 years old in this school can use the long and complex language structure. Itfoundwhen the learners told about what they had read using 
their own language. Learners also had expressed their opinions in groups. Learners were also found involved in discussion with their friends beside them.

They also acted as a listener who likes to think. It is seen when they listened totheir seatmate's opinions, the learners listened with seriously. The facial features of the learner are not empty (has meaning). Learners wereseemed focus on listening totheir friends' sentences. Learners were not just silent after his friend spoke. Her friend's conversation was replied with the argument she was thinking about. The same fact was also found when learners listened and responded to their friends 'opinions during group discussions, and listened and responded to their friends' stories in front of the class.

Learners have a tendency to prioritize reading activities for learning. From the fact, it found that learners tend to open textbooks inthe learning process. Learners opened a book for a specific page if asked by the teacher. However, it is also found that learners open books on certain pages to find the information needed during the learning process.

The intellectual characteristics of 6-9 year old students in SD Negeri 41 Sawahan district of Padang Timur and SD Adzkia Kuranji district, Padang City that learners have the abilityto think deductively and inductively. The proof, learners were able to give the feedback to the contents of the text readings orally.

Learners have the ability to think analysis or they begin to think critically. Critical thinking was shown by learners in the learning process in responding the statement in the book. In addition, besides they could respondthestatements in the book, they also responded the opinions of their friends in the group. It was also found thatlearners could respond the something that they haddiscussed in theclass.

The language used by the learners began communicatively. When telling the stories, the other learners were able to understand the story that the learner was told. The words were used by the learners could make the other person gave a response to what he was told. It means that learners are able to analyze the relationships as verbally that emphasize the use of logic.

Characteristics of physical-motor development of students aged 6-9 years in SD Negeri 41 Sawahan district of East Padang and Adzkia Elementary Kuranji district, Padang City is performed various movements with a clear purpose. Forexamples is the learner activities which involved physical in performing their duties can be seen from their eyes movements. Eyes movements were shown when the learners staredat the other person. In addition,besides this eyes movements, it was also found at the movement of the learners' hands. The learner's hand moved while explaining her opinion. This indicates that the learners tried to convince the other person. This action was found when they were discussing.

Other activities are found in relation to physical movements was the efforts of learners to move their hands while searching for a particular page. A common activity is found in which learners use their hands to write. It means that the learners are able to write and hold the book.

Learners also have an agile motor activity. The activity is shown when the learner raised his hand quickly when They wanted to ask some questions. The learner also raised his hand quickly when he wanted to answer the questions from the teacher. Other agile activities were also found when learners had quickly responded when asked by teachers to do certain tasks.

Characteristics of emotional development of students aged 6-9 years in SD Negeri 41 Sawahan district of Padang Timur and Adzkia Elementary School Kuranji district, Padang City is the learners are accustomed to having a good friendship. Friendship activities were as done by the learners is based on with the environment which is considered good. This tendency is found when they had the peer tutor communication. Learners were preferred to choose a good friend according to them.

In the morning, the learners showed high spirits in the learning process of Indonesian language lesson. This activity performed to look more active. Learners also are shown a sense of curiosity about what he was learning. These show that learners have a passion for learning.

Learners have respectful or appreciative of themselves and others. This attitude is shown when learners knew their friends did not carry stationery, like a pen. Learners directly lent the pen to them. Because he has more than one pen. Respect is also indicated by the actions of learners when students asked the questions to their friends. Their friends directly gave positive responses by explaining what is understood about the material to their friends in their own language.

Characteristics of social development of students aged 6-9 years in SD Negeri 41 Sawahan district of Padang Timur and Adzkia Elementary school Kuranji district, Padang City is the learners are able and accustomed to working together. This action occurs when working in groups. Learners will listen to his friend's opinion. Learners are also able to share tasks in groups. The group leader sets up each task, such as the chairman as a guide what will be done. While one of the friends was appointed to write the results of the discussion. That is, besides they accustomed to working together, learners are also able to work in groups.

Learners are interested in peer activities. This activity is shown when learners have finished doing their individual tasks, next will be questioning between peer tutors. Learners also had a correction of their friends' task. Discussion activities in the group are also often shown in the learning process. Mini discussions often occurred without being asked between seatmate.

\section{Needs Analysis}

The purpose of needs analysis is to examine more deeply about the various aspects needed to achieve an effective learning process. Effective learning can not be separated from the use of teaching materials in the learning process. These teaching materials can help students to understand the characters and apply it in daily activities. Therefore, needs analysis is focused on the analysis of the problems contained in teaching materials used by teachers and learners during the learning process. To develop effective teaching materials, of course, it also needs an effective RPP (lesson plan).

Based on the observations made in SD Negeri 41 Sawahan, Padang Timur District and Adzkia Elementary School, Kuranji district of Padang City, the theme of thematic learning that will be developed is healthy and nutritious food, so it takes data about students related to various things that are liked, including favorite foods and drinks. The data of the 
students' needs of the Padang city consist of the reading hobby, favorite color, favorite food, favorite picture, favorite fruit, favorite vegetables, and favorite drink. This data can be referenced by the author in designing and developing teaching materials. One of the things considered in developing teaching materials is the characteristics of students.

The result of the observation shows that students at the age of 6-9 years enjoy reading as much as 19 students, enjoying the hobby of learning as many as 7 students, like playing as much as 64 students, cooking hobby as much as 5 students, like drawing as much as 11 students, 8 students, love the hobby of coloring as much as 2 students, enjoying the hobby of washing as much as 1 student, enjoying singing hobby as much as 6 students, enjoying the hobby of fishing as much as 4 students, enjoying the hobby of music as many as 7 students, enjoying the dancing hobby as much as 3 students, 9 students. That is, most or $50.79 \%$ of students have a hobby of playing. Teaching materials that will be based on the students'dominant preference are playing activities. The results of observation can be seen in chart 1 below.

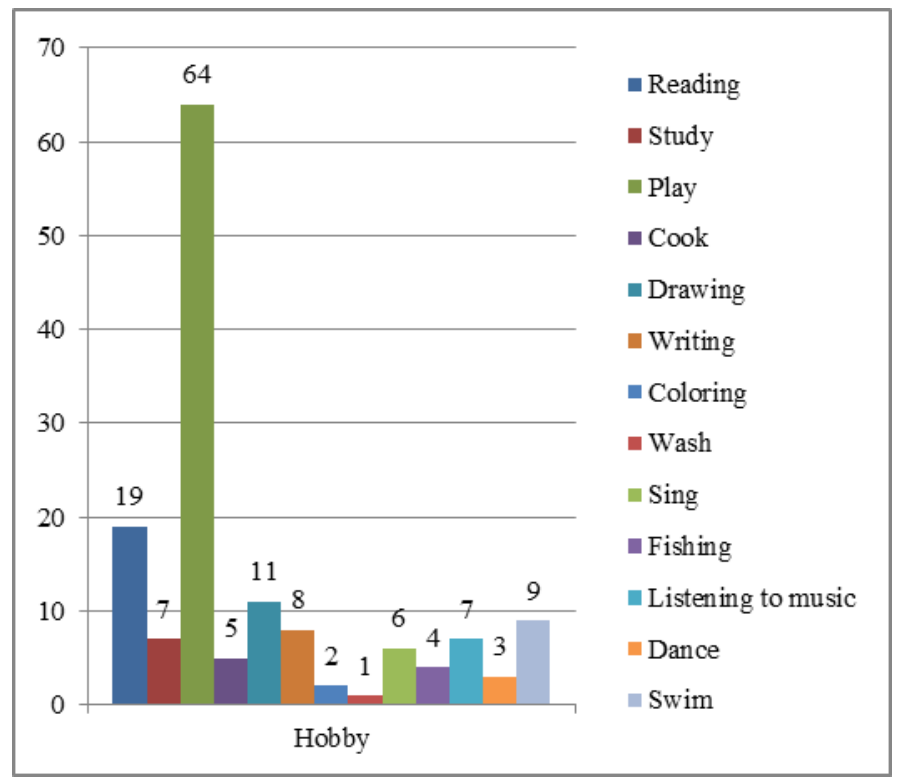

Chart 1. Student Hobby Data Padang City

Observation of student favorite color data shows that students at 6-9 years old like blue color as many as 23 students, like red color as many as 48 students, like green color as many as 14 students, like a purple color as many as 8 students, like white color as much as 3 students, orange as many as 11 students, like black color as much as 3 students, like the color pink as many as 19 students, and like the color yellow as many as 18 students. That is, $38.10 \%$ of students like the color red. The teaching materials to be made based other students'dominant preference of students is red. The results of observation can be seen in the following chart 2 .

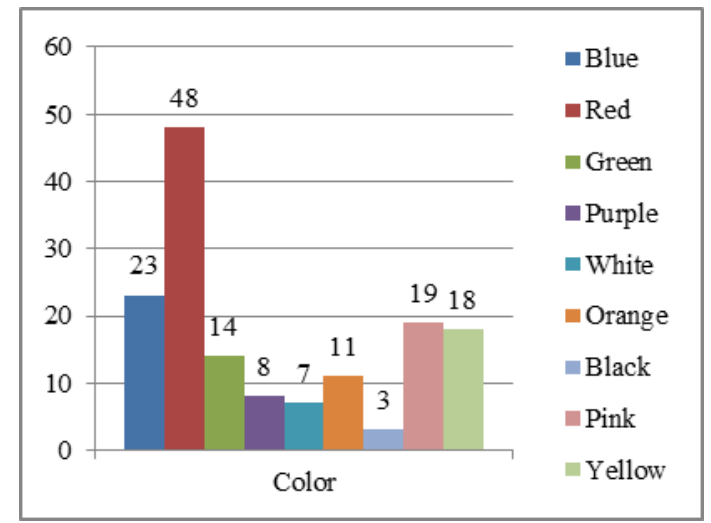

Chart 2. Data of Student's Color of Padang City

Observation of student favorite food data shows that students at the age of 6-9 years like to eat chicken basic ingredients as much as 68 students, like eating soup as many as 6 students, like eating fried rice as much as 22 students, like eating rendang as many as 17 students, like eating martabak egir 3 students, love to eat noodles as much as 4 students, like to eat pizza as much as 8 students, like to eat food with eggs basic ingredients as much as 2 students, like to eat jerky as many as 8 students, like to eat with food with fish basic ingredients as much as 20 students, and likes to eat bread as much as 1 student . That is, $53.97 \%$ of students like to eat food with chicken basic ingredients. Teaching materials to be made can be based on the students' dominant preference isthe food with chickenbasic ingredients. The results of observation can be seen in chart 3 below.

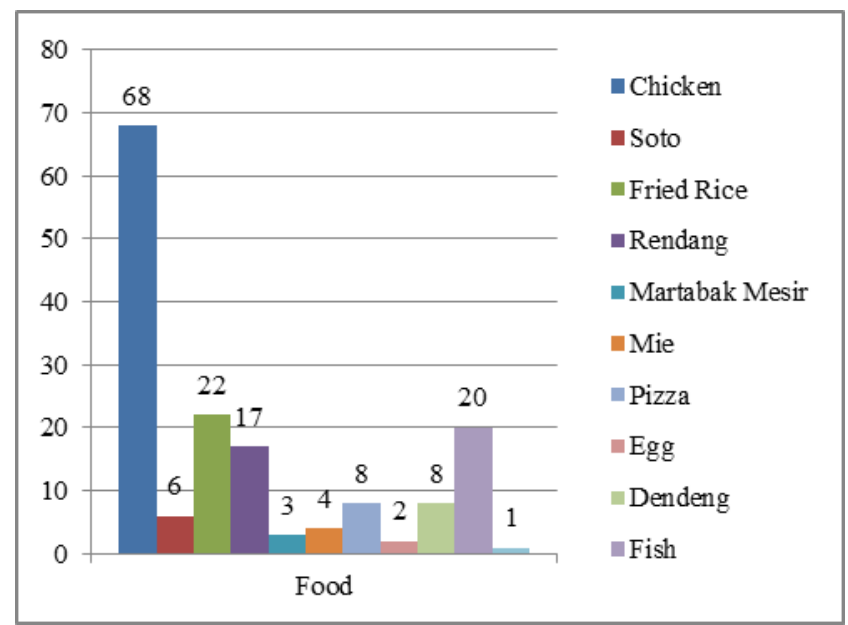

Chart 3. Student Food Data Padang City

Observation of student favorite data shows that the students at the age of 6-9 years like cartoon characters as much as 47 students, like scenery pictures as many as 41 students, like pictures of objects or tools as many as 17 students, like environmental pictures as many as 11 students, students, and love the image of war as much as 2 students. That is, $37.30 \%$ of students love the cartoon image. The instructional material to be created can be based on the students dominantpreference is the cartoon image. The results of observation can be seen in chart 4 below. 


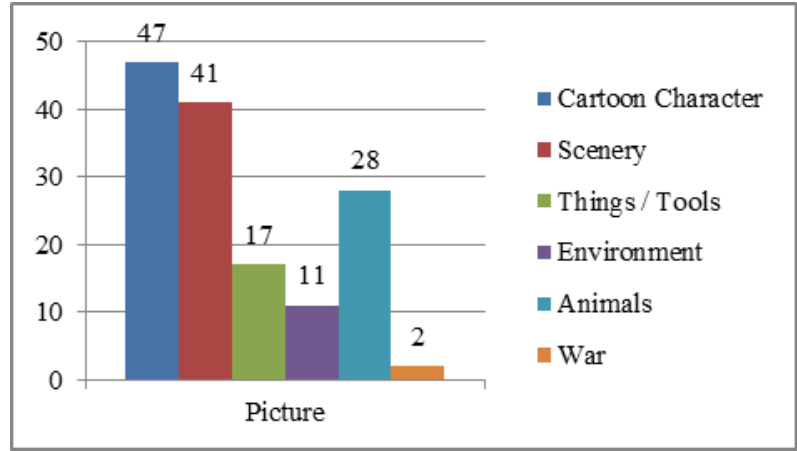

Chart 4. Data of Student's Picture of Padang City

Observation data of students favorite fruit showed that students at the age of 6-9 year like mangosteen fruit as much as 2 students, like fruit strawberry as many as 18 students, like grapes as many as 41 students, like dragon fruit as many as 14 students, like pear as many as 5 students, apple fruit as many as 53 students, like banana fruit as much as 14 students, likes citrus fruit as many as 34 students, like durian fruit as many as 21 students, like melon fruit as much as 30 students, like pineapple fruit as many as 4 students, and likes watermelon fruit as much as 2 students. That is, most or $42.06 \%$ of students love apples. Teaching materials to be made can be directed to the discussion about the apple. The results of observation can be seen in chart 5 below.

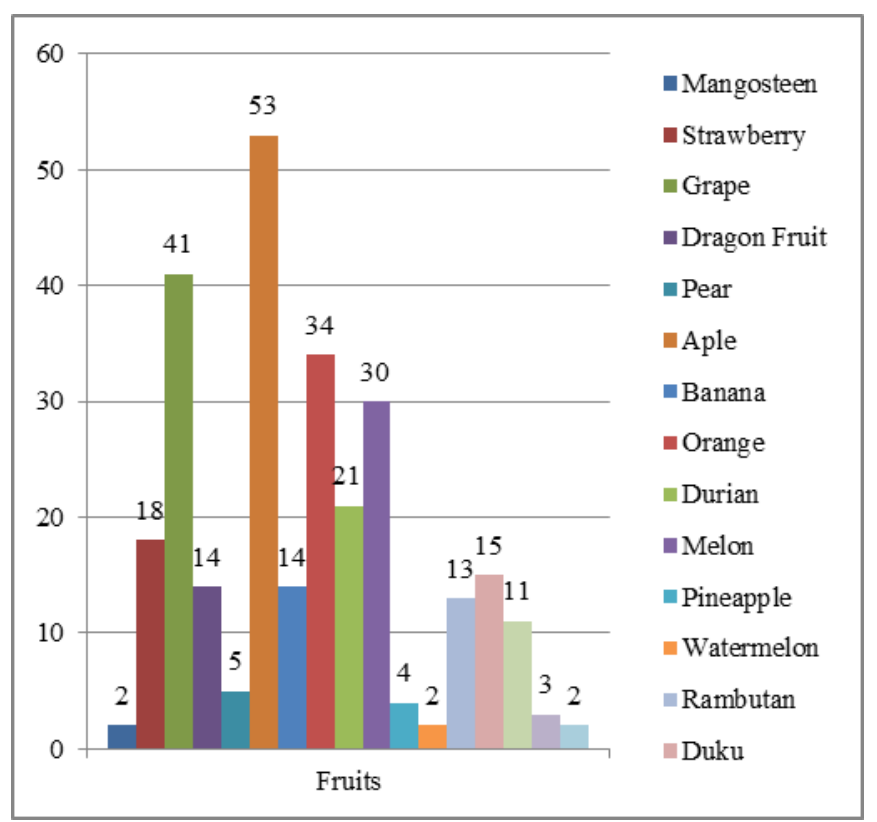

Chart 5. Data of Student's Fondness of Padang City

Observation of the favorite vegetables data showed that students at the age of 6-9 years like to eat spinach as much as 61 students, like to consume kale as much as 52 students, like to eat vegetables broccoli as many as 8 students, like mengonsumsi cabbage as much 4 students, like to eat carrot as many as 29 students, enjoying hobbies like eating mustard vegetables as many as 7 students, like to eat vegetable toge as many as 11 students, like to consume bean as much as 2 students, and like to consume potato as many as 14 students. That is, $48.41 \%$ of students love to eat spinach. Teaching materials to be made can be directed to the discussion of spinach. The results of observation can be seen in the following chart 6 .

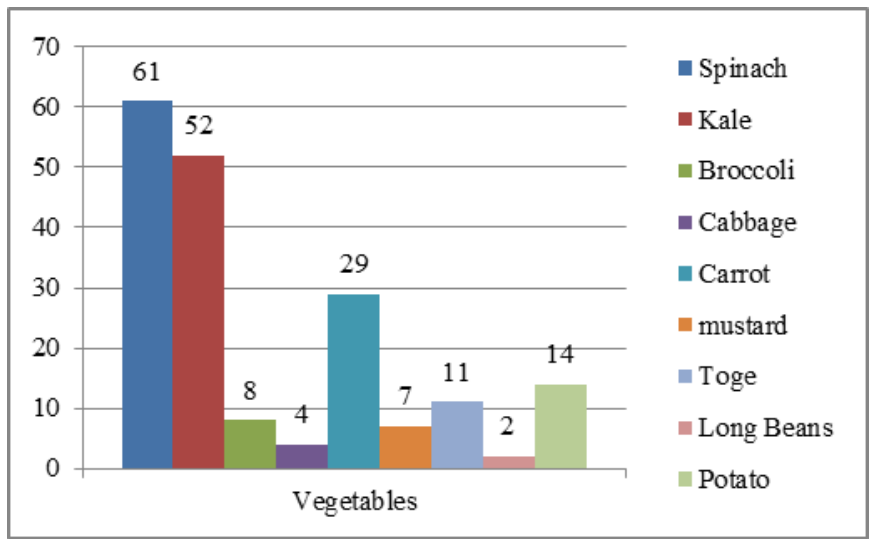

Chart 6. Data of Student's Vegetables of Padang City

Observation of student favorite beverage data showed that students at the age of 6-9 years like to drink fruit juice as much as 86 students, like to drink syrup as much as 1 student, like drinking tea as much as 41 students, like drinking coffee as much as 2 students, like drinking soda as many as 5 students, like drinking mineral water as much as 21 students, and like drinking milk as much as 20 students. That is, $68.25 \%$ of students like to drink fruit juice. Teaching materials to be made can be directed to the discussion of fruit juice. The results of observation can be seen in chart 7 below.

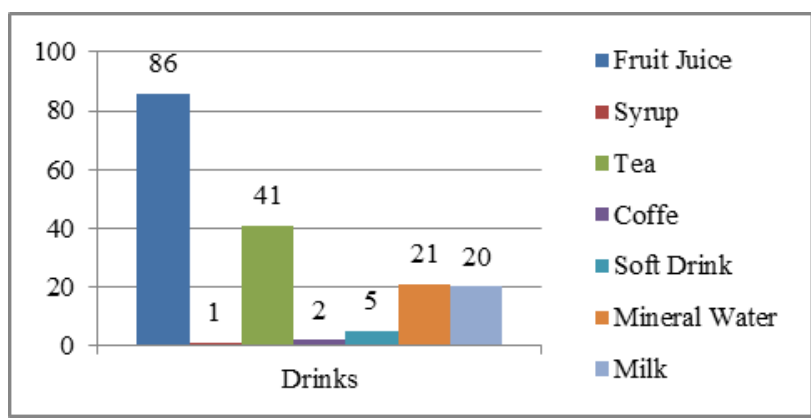

Chart 7. Student Drink Data of Padang City

\section{CONCLUTION}

Based on the discussion of research findings that have been done can be concluded that at the preliminary research stage, children aged 6-9 years require integrated thematic materials based on character education. The teaching materials will be made according to the character of the students as well as the things they like. Most students have a hobby of playing with various types of games with a percentage of $50.79 \%$, like the color red with a percentage of $38.10 \%$, like food with chicken basic ingredients with $53.97 \%$ percentage, likes cartoon characters with percentage $37.30 \%$, likes apples with percentage $42.06 \%$, likes spinach with percentage $48.41 \%$, and likes kind of fruit juice drink with percentage $68,25 \%$. This analysis shows an early description of the character of children aged 6-9 years which is very useful in making 
teaching materials for the realization of character building. This data can be referenced by the author in designing and developing teaching materials. One of the things considered in developing teaching materials is the characteristics of students.

\section{Acknowledgment}

Authors would like to thank all those who contributed to completion of this article. Thanks also to the research fund provider, RISTEK-DIKTI at Indonesia.

\section{References}

[1] A. Lumpkin and S. Stokowski, "Interscholastic Sports: A CharacterBuilding Privilege," Kappa Delta Pi Rec., vol. 47, no. 3, pp. 124-128, 2011.

[2] H. W. Marsh and S. Kleitman, "Consequences of employment during high school: character building, subversion of academic goals, or a threshold?," Am. Educ. Res. J., vol. 42, no. 2, pp. 331-369, 2005.

[3] B. S. JORGENSEN and R. C. STEDMAN, "Sense of Place As an Attitude: Lakeshore Owners Attitudes Toward Their Properties," $J$. Environ. Psychol., vol. 21, no. 3, pp. 233-248, 2001.

[4] I. Ali, G. Radice, and J. Kim, "Backstepping Control Design with Actuator Torque Bound for Spacecraft Attitude Maneuver," J. Guid. Control. Dyn., vol. 33, no. 1, pp. 254-259, 2010.

[5] T. Lickona, "A Comprehensive Approach to Character Building in Catholic Schools," Cathol. Educ. A J. Inq. Pract., vol. 1, no. 2, pp. 159-175, 1997.

[6] I. Ajzen and M. Fishbein, "Attitude-behavior relations: A theoretical analysis and review of empirical research.," Psychol. Bull., vol. 84, no. 5, pp. 888-918, 1977.

[7] Depdiknas, Kurikulum Tingkat Satuan Pendidikan (KTSP) Pelajaran Bahasa Indonesia. Jakarta: Puskur-BNSP, 2006.

[8] Kemendikbud, Panduan Teknis Kurikulum2013 di SD. Jakarta: Kemendikbud, 2014.

[9] C. G. Lord, L. Ross, and M. R. Lepper, "Biased assimilation and attitude polarization: The effects of prior theories on subsequently considered evidence.," J. Pers. Soc. Psychol., vol. 37, no. 11, pp. 20982109, 1979.

[10] J. S. Benninga, M. W. Berkowitz, P. Kuehn, and K. Smith, "Char acter and A cademics:," PHI Delta Kappan, vol. 87, no. 6, pp. 448-452, 2006.

[11] J. M. Feldman and J. G. Lynch, "Self-generated validity and other effects of measurement on belief, attitude, intention, and behavior.," $J$. Appl. Psychol., vol. 73, no. 3, pp. 421-435, 1988.

[12] D. F. Jennings and S. L. Seaman, "Aggressiveness of response to new business opportunities following deregulation: An empirical study of established financial firms," J. Bus. Ventur., vol. 5, no. 3, pp. 177-189, 1990.

[13] B. Gawronski and G. V. Bodenhausen, "Associative and propositional processes in evaluation: An integrative review of implicit and explicit attitude change.," Psychol. Bull., vol. 132, no. 5, pp. 692-731, 2006.

[14] W. R. Van Joolingen, T. De Jong, A. W. Lazonder, E. R. Savelsbergh, and S. Manlove, "Co-Lab: Research and development of an online learning environment for collaborative scientific discovery learning," Comput. Human Behav., vol. 21, no. 4, pp. 671-688, 2005.

[15] T. De Jong and W. Van Joolingen, "Scientific discovery learning with computer simulations To cite this version : HAL Id : hal-00190680," 2007.

[16] P. A. Kirschner, J. Sweller, and R. E. Clark, "Why Minimal Guidance During Instruction Does Not Work," Educ. Psychol., vol. 41, no. March 2015, pp. 87-98, 2006.

[17] J. E. Tuovinen and J. Sweller, "A comparison of cognitive load associated with discovery learning and worked examples.," J. Educ. Psychol., vol. 91, no. 2, pp. 334-341, 1999.

[18] R. E. Mayer, "Should There Be a Three-Strikes Rule Against Pure Discovery Learning?," Am. Psychol., vol. 59, no. 1, pp. 14-19, 2004.

[19] T. Lickona, Educating for Character. Jakarta: Aksara, 2012.

[20] N. A. Wiyani, Membumikan Pendidikan karakter di SD. Yogyakarta: Ar-Ruzz Media, 2013.

[21] Zubaedi, Desain Pendidikan Karakter. Jakarta: Kencana, 2012.

[22] M. Yamin, Kiat Membelajarkan Siswa. Jakarta: Gaung Persada Press, 2011.

[23] Plomp and Nieveen, An Introduction to Educational Design Research. 2013. 